\title{
HUBUNGAN LAMA HEMODIALISA DENGAN STATUS NUTRISI PADA PASIEN GAGAL GINJAL KRONIK DI RUANG HEMODIALISA
}

\section{THE CORRELATION OF LONG TERM HEMODIALYSIS WITH NUTRITIONAL STATUS ON CHRONIC KIDNEY DISEASE PATIENTS IN HEMODIALYSIS UNIT}

\section{Dewi Ratnasari ${ }^{1}$, Nur Isnaini ${ }^{2}$}

Fakultas IImu Kesehatan Universitas Muhammadiyah Purwokerto

Email: ratna.rs9898@gmail.com

\begin{abstract}
ABSTRAK
Pendahuluan: Penyakit Ginjal Kronik adalah kerusakan fungsi ginjal yang terjadi selama 3 bulan atau lebih. Gangguan gastrointestinal berupa mual, muntah, dan kehilangan nafsu makan dapat merubah status nutrisi. Penilaian status nutrisi adalah komponen utama dalam evaluasi dan penatalaksanaan pasien. Tujuan: Mengetahui hubungan lama hemodialisa dengan status nutrisi pada pasien PGK. Metode: Penelitian ini merupakan penelitian kuantitatif dengan desain observasional analitik menggunakan pendekatan cross sectional. Uji yang digunakan pada penelitian ini adalah Uji Chi-Square. Pengambilan sampel dengan menggunakan accidental sampling. Hasil: penelitian ini menghasilkan nilai tertinggi pada status nutrisi normal dengan lama $\mathrm{HD}>12$ bulan, hal ini disebabkan karena seseorang yang telah lama menjalani hemodialisa mulai terbiasa dengan keadaan gangguan gastrointestinal seperti mual, muntah, diare. Semakin lama orang menjalani hemodialisa, semakin memberikan peluang bagi pasien untuk lebih adaptif dengan program terapi yang dijalaninya. Kesimpulan: Tidak terdapat hubungan yang bermakna antara lama hemodialisa dengan status nutrisi.
\end{abstract}

Kata Kunci : Lama hemodialisa, Penyakit Ginjal Kronik, Status nutrisi

\begin{abstract}
Introduction: Chronic Kidney Disease is a deterioration of kidney function that occurs for 3 months or more. Gastrointestinal disorders such as nausea, vomiting, and loss of appetite can change their nutritional status. Nutritional status assessment is a major component in evaluating and managing patients. Purpose: This research aimed to discover the correlation of the duration of hemodialysis and the nutritional status of patients with Chronic Kidney Disease. Method: This was a quantitative research with an analytic observational design and a cross-sectional approach. The test used in this study was the Chi-Square test. Sample using an accidental sampling method. Results: This study obtained the highest value on normal nutritional status with HD duration $>12$ months, this was caused the person who has undergone hemodialysis for long duration has become accustomed to gastrointestinal disorders, such as nausea, vomiting, and diarrhea. The longer duration for people undergo hemodialysis, the more hemodialysis provides opportunities for patients to be more adaptive to the therapeutic program that they are undergoing. Conclusion: There was no significant correlation between the duration of hemodialysis and patients' nutritional status.
\end{abstract}

Keywords: Chronic Kidney Disease, Duration of hemodialysis, Nutritional status
JURNAL

SKOLASTIK

\section{KEPERAWATAN}

VOL. 6 , NO. 1 Januari - Juni 2020

ISSN: $2443-0935$

E-ISSN 2443 - 16990 


\section{PENDAHULUAN}

Penyakit Ginjal Kronik (PGK) adalah masalah kesehatan masyarakat global. PGK terjadi berdasarkan adanya kerusakan fungsi ginjal atau penurunan Laju Filtrasi Glomerulus (LFG) kurang dari $60 \mathrm{~mL} / \mathrm{min} / 1,73 \mathrm{~m}^{2}$, LFG dianggap sebagai indeks penentu fungsi ginjal (Himmelfarb dan Ikizler, 2019). Menurut herman (2016) klasifikasi PGK di dasarkan atas dua hal yaitu, atas dasar derajat (stage) penyakit dan atas dasar diagnosis etiologi.

Berdasarkan Riset Kesehatan Dasar atau Riskesdas tahun 2018, jumlah penduduk Indonesia mencapai 258 juta jiwa dan prevalensi penderita PGK di Indonesia yang telah didiagnosis dokter berdasarkan provinsi sebesar 3,8 \%. Dalam data Indonesia Renal Registry (Renal, Registry, \& Course, 2017) penyebab PGK terbesar adalah penyakit ginjal karena hipertensi sebesar $36 \%$ dan nefropati diabetika sebesar $29 \%$.

Penderika PGK di Jawa Tengah sendiri mengalami peningkatan sebesar 0,06\%. Tahun 2013 Jawa Tengah memiliki nilai prevalensi sebesar 0,3\% dan pada riskesdas tahun 2018 dengan nilai prevalensi sebesar $0,37 \%$ per penduduk Jawa Tengah (Dinas Kesehatan Jateng, 2017). Orang yang didiagnosis terkena PGK harus menjalani hemodialisa, frekuensi tindakan hemodialisis biasanya dilakukan satu hingga tiga kali seminggu untuk total 9 sampai 12 jam. Frekuensi tindakan hemodialisis bervariasi tergantung banyaknya fungsi ginjal yang tersisa (Priscilla et al, 2018).

Kerusakan dan menurunnya nefron dengan kehilangan fungsi ginjal yang progresif. Ketika LFG menurun dan bersihan menurun, nitrogen ureum serum meningkat dan kreatinin meningkat. Nefron tersisa yang masih berfungsi mengalami hipertrofi ketika mereka menyaring zat terlarut yang besar. Akibatnya, ginjal kehilangan kemampuan untuk mengonsentrasi urin secara adekuat.

Hemodialisa dapat didefinisikan sebagai suatu proses pengubahan komposisi solut darah oleh larutan lain (cairan dialisat) melalui membran semipermeabel (membran dialisis). Prinsipnya hemodialisis adalah suatu proses pemisahan atau penyaringan atau pembersihan darah melalui suatu membran yang semipermeabel yang dilakukan pada pasien dengan gangguan fungsi ginjal baik yang kronik maupun akut (Setiati et al, 2014).

Semakin lama orang menjalani hemodialisa, memberikan peluang bagi pasien untuk lebih adaptif dengan program terapi. Di sisi lain, semakin lama menjalani hemodialisa juga semakin tinggi potensi munculnya komplikasi yang justru dapat menghambat kepatuhan terhadap program terapi (Pranoto, 2010).

Masalah lain pasien PGK yang menjalani hemodialisa adalah tingginya angka malnutrisi. Prevalensi malnutrisi pasien PGK yang menjalani hemodialisis berkisar 18-75\%. Malnutrisi adalah salah satu masalah kesehatan karena pola diet yang tidak tepat yaitu kompilasi tubuh tidak mendapatkan sebuah asupan yang tepat dari vitamin, mineral, dan nutrisi yang dibutuhkan oleh jaringan dan fungsi organ.

Penilaian status nutrisi dilakukan untuk mengukur status gizi seseorang, termasuk di dalamnya untuk mengukur status malnutrisi pada pasien hemodialisa. International Society of Renal Nutrition and Metabolism (ISRNM) menetapkan kriteria diagnostik status nutrisi pasien PGK, yaitu: kriteria biokimia yang dinilai dari serum albumin, prealbumin /transtiretin dan serum kolesterol, masa tubuh yang dinilai dari Indeks Masa Tubuh (IMT) dan persentase lemak tubuh, masa otot 
yang dinilai dari kadar serum kreatinin dan Midarm Muscle Circumference (MMC) atau Lingkar Otot Lengan Atas (LOLA), intake makanan atau nutrisi (Rahman, Kaunang, \& Elim, 2016), (Marcelli et al., 2015).

Menurut Santoso (2016) perubahan setelah dilakukan hemodialisa kemampuan ginjal pada penderita PGK dalam mengeluarkan hasil metabolisme tubuh terganggu sehingga sisa metabolisme tersebut menumpuk dan menimbulkan gejala klinik dan laboratorium yang disebut sindrom uremik. Sindrom uremik akan menimbulkan gejala berupa penurunan hemoglobin, gangguan kardiovaskular, gangguan kulit, gangguan system syaraf, dan Gangguan gastrointestinal yang umum terjadi pada pasien hemodialysis berupa mual, muntah, dan kehilangan nafsu makan sehingga dapat terjadi perubahan pada status nutrisinya.

Hasil studi pendahuluan yang dilakukan di RS Islam Purwokerto, didapatkan pasien rutin yang menjalani Hemodialisa sebanyak 57 orang, 53 orang melakukan hemodialisa dua kali di dalam seminggu, 4 orang melakukan hemodialisa satu kali di dalam seminggu. Pengecekan kadar hemoglobin dilakukan setiap 1 bulan satu kali, pengecekan kadar kreatinin dan kadar ureum dilakukan 3 bulan satu kali. Status nutrisi pasien jarang sekali terkontrol dan tercatat dalam asuhan keperawatan. Penimbangan dilakukan setelah melakukan hemodialisa. Saat salah satu pasien diwawancarai mengenai berat badan, pasien dan keluarga menjawab ada penurunan setiap kali melakukan hemodialisa.

Tujuan penelitian ini untuk mengetahui adakah hubungan lama hemodialisa dengan status nutrisi pada pasien penyakit ginjal kronik di ruang hemodialisa RS Islam Purwokerto.

\section{BAHAN DAN METODE}

Penelitian ini merupakan penelitian kuantitatif dengan desain penelitian observasional analitik menggunakan pendekatan cross sectional. Teknik pengumpulan data dengan menggunakan lembar observasi dan melakukan pengukuran tinggi badan, berat badan untuk mendapatkan hasil nilai Indeks Masa Tubuh (IMT) responden, data pendukung dengan cara wawancara terpimpin dan merujuk pada rekam medis pasien dengan kriteria inklusi: pasien PGK yang menjalani HD di RSIP, sudah menjalani HD minimal 1 minggu, bersedia menjadi responden. Eksklusi: pasien tidak hadir saat penelitian, pasien baru $<1$ minggu, pasien menolak menjadi responden. Penelitian ini dilakukan selama 2 minggu dimulai pada tanggal 25 November - 7 Desember 2019 di Rumah Sakit Islam Purwokerto. Metode pengambilan sample yang digunakan adalah dengan acidental sampling.

\section{HASIL}

Berdasarkan Tabel.1 dapat dijelaskan bahwa karakteristik responden yang menjalani hemodialisa di RS Islam Purwokerto berdasarkan kategori jenis kelamin terbanyak adalah dengan jenis kelamin perempuan yakni sebanyak 33 responden $(64,7 \%)$ dan laki-laki sebanyak 18 responden (35,3\%). Hasil penelitian ini sesuai dengan hasil penelitian dari Widyastuti (2014) yang menyatakan bahwa pasien perempuan yang menjalani HD sebanyak $52 \%$ dan laki-laki sebanyak $48 \%$.

Pada dasarnya dari beberapa literatur dijelaskan bahwa jenis kelamin tidak mempengaruhi terjadinya PGK, karena laki-laki dan perempuan memiliki risiko yang sama untuk menderita PGK (Hermawati,2017). 
Tabel 1. Karakteristik responden

\begin{tabular}{lcc}
\hline \multicolumn{1}{c}{ Karakteristik responden } & N & Presentase (\%) \\
\hline Jenis kelamin: & 18 & 35,3 \\
Laki-laki & 33 & 64,7 \\
Perempuan & & \\
\hline Kelompok Usia : & 1 & 2,0 \\
17-25 (remaja akhir) & 3 & 5,9 \\
26-35 (dewasa awal) & 11 & 21,6 \\
36-45 (dewasa akhir) & 19 & 37,3 \\
46-55 (lansia awal) & 12 & 23,5 \\
56-65 (lansia akhir) & 5 & 9,8 \\
$>65$ (manula) & &
\end{tabular}

\section{Pendidikan:}

Tidak Sekolah

\begin{tabular}{lcc} 
SD & 5 & 9,8 \\
SMP & 12 & 23,5 \\
SMA & 9 & 17,6 \\
PT & 17 & 33,3 \\
& 8 & 15,7 \\
\hline Pekerjaan : & & \\
Tidak Bekerja & 5 & 9,8 \\
IRT & 26 & 51,0 \\
Wiraswasta & 12 & 23,5 \\
Petani & 5 & 9,8 \\
PNS & 3 & 5,9
\end{tabular}

\section{Penghasilan}

$\begin{array}{lcc}<\text { 1juta } & 1 & 2,0 \\ 1-2 \text { juta } & 38 & 74,5 \\ >\text { 2juta } & 12 & 23,5\end{array}$

$\begin{array}{lll}\text { Lama HD } & & \\ \leq 12 \text { bulan } & 16 & 31,4 \\ >12 \text { bulan } & 35 & 68,6\end{array}$

\begin{tabular}{lcc}
\hline Riwayat Penyakit & & \\
Hipertensi & 29 & 56,9 \\
Dispepsia & 1 & 2,0 \\
DM & 5 & 9,8 \\
CKD & 11 & 21,6 \\
Post TB & 2 & 3,9 \\
CHF & 1 & 2,0 \\
Anemia & 1 & 2,0 \\
Asam Urat & 1 & 2,0 \\
\hline Total & $\mathbf{5 1}$ & $\mathbf{1 0 0}$ \\
\hline
\end{tabular}

Kategori usia terbanyak adalah lansia awal usia 46-55 tahun yakni sebanyak 19 responden $(37,3 \%)$, hasil ini selaras dengan penelitian Garini (2018) yang menyatakan bahwa semakin bertambah umur, ginjal menjadi berkurang kemampuannya dalam merespon cairan elektrolit yang akut dan semakin berisiko mengalami malnutrisi.

Sebagian besar responden berlatar belakang pendidikan SMA yakni sebanyak 17 responden (33,3\%), senada dengan penelitian Wulandari (2015) pendidikan dengan status gizi 
baik mayoritas SMA (28,3\%). Bagi seseorang yang memiliki pengetahuan tinggi tentang gizi, pemenuhan makanan yang bergizi tidak harus mahal, namun bisa diusahakan di pekarangan rumah sendiri. Suparti (2016) mempunyai pandangan responden yang berpendidikan tinggi dan rendah punya cara tersendiri untuk mencari informasi terkait penyakitnya dan perawatannya. Mereka samasama tidak peduli dengan kondisi yang mereka alami saat ini, yang mereka tahu saat ini hanya berobat supaya sembuh tanpa memikirkan kebutuhan yang menunjang akan kualitas hidupnya.

Kategori pekerjaan yang terbanyak adalah IRT sebanyak 26 responden (51,0\%). Dalam penelitian Ullu (2018) penderita PGK lebih cepat merasa lelah, lesu, nyeri sendi, nafas pendek dan berbagai gejala lainnya yang membuat pasien tidak maksimal dalam bekerja. Hal ini berkaitan dengan rasa lelah yang berlebih sehingga mayoritas responden memilih untuk bekerja di rumah, dengan penghasilan responden mayoritas adalah 1-2 juta dengan 38 responden $(74,5 \%)$.

Berdasarkan lama HD 1-12 bulan sebanyak 16 responden $(31,4 \%)$ dan lebih dari 12 bulan sebanyak 35 responden $(68,6 \%)$. Menurut pranoto (2010) semakin lama orang menjalani hemodialisa, memberikan peluang bagi pasien untuk lebih adaptif dengan program terapi. Di sisi lain, semakin lama menjalani hemodialisa juga semakin tinggi potensi munculnya komplikasi yang justru dapat menghambat kepatuhan terhadap program terapi.

Sebagian besar riwayat penyakit yang diderita responden adalah Hipertensi yakni sebanyak 29 responden (56,9\%). Hasil penelitian ini sejalan dengan penelitian Astrini (2013) yang menyebutkan bahwa mekanisme terjadinya hipertensi yang terjadi akibat PGK adalah penurunan aliran darah ke ginjal serta Laju Filtrasi Glomerulus (LFG) yang berkurang yang dapat meningkatkan aktivitas sistem Renin Angiotensin Aldosteron (RAA). Selaras dengan penelitian Pongsibidang (2017) yang menyatakan bahwa orang yang memiliki penyakit hipertensi 21,45 kali lebih berisiko mengalami penyakit gagal ginjal kronik dibandingkan dengan mereka yang tidak memiliki penyakit hipertensi.

Tingginya tekanan darah akan membuat pembuluh darah dalam ginjal tertekan. Akhirnya, pembuluh darah menjadi rusak dan menyebabkan fungsi ginjal menurun hingga mengalami kegagalan ginjal. Salah satu dampak jangka panjang dari tekanan darah tinggi adalah ketika pembuluh darah yang menyuplai ginjal terkena dampaknya dapat mengakibatkan kerusakan ginjal secara bertahap. Semakin lama menderita hipertensi maka semakin tinggi risiko untuk mengalami kejadian gagal ginjal kronik (Pongsibidang,2017).

Berdasarkan Tabel.2 dapat diketahui bahwa tidak ada hubungan antara lama HD dengan status nutrisi di ruang hemodialisa RS Islam Purwokerto. Nilai Pearson Chi square sebesar 0,221 dengan nilai $p \geq 0,05$ yang menunjukkan tidak ada hubungan antara lama HD dengan status nutrisi.

Pada penelitian ini menghasilkan nilai tertinggi pada status nutrisi normal dengan lama HD $>12$ bulan, hal ini disebabkan karena seseorang yang menjalani hemodialisa sudah mulai terbiasa dengan keadaan gangguan gastrointestinal seperti mual, muntah, diare. Sejalan dengan penelitian dari Pranoto (2010) semakin lama orang menjalani hemodialisa, semakin memberikan peluang bagi pasien untuk lebih adaptif dengan program terapi yang dijalaninya. 
Tabel 2. Hubungan lama hemodialisa dengan status nutrisi

\begin{tabular}{|c|c|c|c|c|c|c|c|}
\hline \multirow{3}{*}{ Lama HD } & \multicolumn{4}{|c|}{ Status Nutrisi } & \multirow{2}{*}{\multicolumn{2}{|c|}{ Total }} & \multirow[t]{3}{*}{$P$-Value } \\
\hline & \multicolumn{2}{|c|}{ Normal } & \multicolumn{2}{|c|}{ Tidak Normal } & & & \\
\hline & $f$ & $\%$ & $f$ & $\%$ & $f$ & $\%$ & \\
\hline$\leq 12$ bulan & 12 & 75 & 4 & 25 & 16 & 100 & 0,221 \\
\hline$>12$ bulan & 20 & 57,1 & 15 & 42,9 & 35 & 100 & \\
\hline Total & 32 & 62,7 & 19 & 37,3 & 51 & 100 & \\
\hline
\end{tabular}

Berdasarkan Tabel.2 dapat diketahui bahwa tidak ada hubungan antara lama HD dengan status nutrisi di ruang hemodialisa RS Islam Purwokerto. Nilai pearson chi square sebesar 0,221 ( $p>0,05)$ yang menunjukkan tidak ada hubungan antara lama HD dengan status nutrisi.

Pada penelitian ini menghasilkan nilai tertinggi pada status nutrisi normal dengan lama HD >12 bulan, hal ini disebabkan karena seseorang yang menjalani hemodialisa sudah mulai terbiasa dengan keadaan gangguan gastrointestinal seperti mual, muntah, diare. Sejalan dengan penelitian dari Pranoto (2010) semakin lama orang menjalani hemodialisa, semakin memberikan peluang bagi pasien untuk lebih adaptif dengan program terapi yang dijalaninya.

\section{PEMBAHASAN}

Hasil penelitian ini sejalan dengan penelitian dari Insani (2019) dengan hasil analisis yang diperoleh tidak terdapat hubungan antara lama menjalani hemodialisa dengan status nutrisi pada pasien PGK dengan $p$ value $\geq 0,05$. Dalam penelitiannya, Insani (2019) menyampaikan untuk melihat gambaran status nutrisi penderita PGK maka hasilnya tergantung dengan jenis penilaian status nutrisi yang digunakan. Penelitian Syaiful (2014) dengan menggunakan metode penilaian status nutrisi Skinfold dan Lila, menyatakan bahwa tidak terdapat hubungan yang bermakna antara status gizi dengan lamanya hemodialisis dengan nilai $p>0,05$ dengan nilai $r<1$.

Berbanding terbalik dengan penelitian Widyastuti (2014) yang menyatakan bahwa terdapat korelasi antara lama menjalani hemodialisis dengan indeks massa tubuh pada pasien gagal ginjal kronik di RSUD Arifin Achmad Provinsi Riau, penghitungan penelitian ini dengan menggunakan uji korelasi Lambda mendapatkan nilai $p<0,05, r$ (kekuatan korelasi) 0,40 dan arah korelasi positif.

Rata-rata berat badan responden di ruang hemodialisa RSIP adalah 58,7 $\mathrm{kg}$ dan untuk IMT rata-rata 23,4 dengan kategori normal. Lingkar lengan atas responden memiliki nilai rata-rata $25,7 \mathrm{~cm}$ dengan nilai tertinggi $40 \mathrm{~cm}$ dan terendah $17 \mathrm{~cm}$, hasil penelitian ini sejalan dengan penelitian Syaiful (2014) yang menjelaskan bahwa tidak ada hubungan yang bermakna status nutrisi (pengukuran lila) dengan lamanya hemodialisa.

Perubahan asupan makan akhir-akhir ini dibandingkan dengan kebiasaan, responden rata-rata mengalami penurunan dari sebelum sakit tahap ringan hal ini terjadi pada responden baru maupun lama. Sedangkan lama dan derajat perubahan asupan makanan pada responden rata-rata $>2$ minggu perubahan ringan-sedang.

Hasil penelitian ini didukung pula dengan penelitian Santoso (2016) yang menjelaskan bahwa pasien yang sudah lama menjalani hemodialisis akan memiliki kadar ureum dan kreatinin yang tinggi. Kadar ureum dan kreatinin 
yang meningkat tersebut dapat merangsang produksi asam lambung, sehingga menyebabkan keluhan seperti sakit maag (gastritis), yaitu mual, muntah, perih ulu hati, kembung dan tidak nafsu makan.

Banyak faktor-faktor lain yang dapat mempengaruhi status nutrisi pada pasien hemodialisa diantaranya tingkat kesadaran pasien terhadap asupan nutrisi, kepatuhan diet, kepatuhan pembatasan cairan, kepatuhan pasien menjalani HD, riwayat penyakit, efek samping obat, adanya dukungan keluarga, adanya gejala gastrointestinal yang berbeda masingmasing individu.

Untuk mengkaji status nutrisi dapat dilakukan dengan beberapa cara diantaranya secara langsung dan tidak langsung. Pada penelitian ini peneliti menggunakan penilaian status nutrisi secara langsung yakni dengan mengobservasi antropometri pasien secara langsung, melihat keadaan

\section{DAFTAR PUSTAKA}

Astrini,W. (2013). Hubungan Kadar Hemoglobin $(\mathrm{Hb})$, Indeks Massa Tubuh (Imt) Dan Tekanan Darah Dengan Kualitas Hidup Pasien Gagal Ginjal Kronik Yang Menjalani Hemodialisis Di Rsud Dokter Soedarso Pontianak Bulan April 2013. (April).

Dinas Kesehatan Jateng. (2017). Profil Kesehatan Provinsi Jawa Tengah 2017. Semarang. Dinkes Jateng. Diakses tanggal 9 september 2019.

Garini, A. (2018). Kadar Hemoglobin Pada Pasien Gagal Ginjal Kronik Yang Menjalani Hemodialisis. Jurusan Analis Kesehatan Poltekkes Palembang. JPP (Jurnal Kesehatan Poltekkes Palembang) Vol., 13(2), 111-116. pasien dan mewawancarai pasien yang bersedia menjadi responden.

\section{KESIMPULAN}

Berdasarkan hasil dan pembahasan peneliti diatas peneliti menyimpulkan sebagai berikut: Nilai Pearson Chi square dari lama hemodialisa dengan status nutrisi sebesar $0,221 \quad(p \geq 0,05)$ yang menunjukkan tidak ada hubungan yang bermakna antara lama hemodialisa dengan status nutrisi. Masih ada banyak metode penilaian status nutrisi yang perlu diteliti dan faktor-faktor lain yang dapat mempengaruhi status nutrisi pada pasien hemodialisa diantaranya tingkat kesadaran pasien terhadap asupan nutrisi, kepatuhan diet, kepatuhan pembatasan cairan, kepatuhan pasien menjalani HD, riwayat penyakit, efek samping obat, adanya dukungan keluarga, adanya gejala gastrointestinal yang berbeda masingmasing individu

Herman, I. (2016). Hubungan Lama Hemodialisis Dengan Fungsi Kognitif Pasien Penyakit Ginjal Kronik Yang Menjalani Hemodialisis Di Rsud Abdul Moeloek Bandar Lampung. Lampung. Fakultas kedokteran Universitas Lampung. Diakses tanggal 25 september 2019.

Himmelfarb, J., \& Ikizler, T. A. (2019). Chronic kidney disease, Dialysis , and Transplantation - a sompanion to Brenner and rector's the kidney (4rd ed.). https://doi.org/10.1016/B978-0323-52978-5.18001-2

Indonesia Renal Registry. (2017). 10th Report Of Indonesia Renal Registry. Jakarta. Indonesia Renal Registry. Diakses tanggal 9 september 2019. 
Insani, A. A., Ayu, P. R., Anggraini, D. I., Ilmu, B., Klinik, P., Kedokteran, F., ... Lampung, M. (2019). Hubungan Lama Menjalani Hemodialisis Dengan Status Nutrisi Pada Pasien Penyakit Ginjal Kronik ( PGK) Di Instalasi Hemodialisa RSUD Dr. H . Abdul Moeloek Provinsi Lampung Program Studi Profesi Dokter , Fakultas Kedokteran, Universitas Lampung The Correlation Between The Duration Of Hemodialysis And Nutritional Status Of Chronic Kidney Disease (CKD) Patients At Hemodialysis Installation Metode Penelitian Penelitian ini bersifat observasional penelitian ini adalah 18 bulan dengan nilai. 8, 55-59.

Pranoto,I. (2010). Hubungan Antara Lama Menjalani Hemodialisa Dengan Terjadinya Perdarahan Intraserebral [Skripsi]. Surakarta: Universitas Sebelas Maret. Diakses tanggal 8 september 2019

Priscilla et al. (2018). Buku Ajar Keperawatan Medikal Bedah : Gangguan Gastrointestinal. Jakarta. EGC

Rahman, M. T. S. A., Kaunang, T. M. D., \& Elim, C. (2016). Hubungan antara lama menjalani hemodialisis dengan kualitas hidup pasien yang menjalani hemodialisis di Unit Hemodialisis RSUP. Prof. Dr. R. D. Kandou Manado. E-CliniC, 4(1). https://doi.org/10.35790/ecl.4.1.20 16.10829.Diakses tanggal 9 september 2019.

Santoso et al. (2016). Hubungan Lama Hemodialisis Dengan Penurunan Nafsu Makan Pada Pasien Gagal Ginjal Kronik Di Unit Hemodialisa RSUD Ulin Banjarmasin. Banjarmasin. STIKES Sari Mulia Banjarmasin. Diakses tanggal 21 september 2019.
Setiati, et al. (2014). Buku Ajar IImu Penyakit Dalam. Jakarta: Interna Publishing. 2194-98.

Suparti. (2016). Perbedaan Kualitas Hidup Pasien Gagal Ginjal Kronik Ditinjau Dari Tingkat Pendidikan, Frekuensi Dan Lama Hemodialisis Di Rsud Goeteng Taroenadibrata Purbalingga. 14(2), 50-58.

Syaiful, H. Q., Oenzil, F., \& Afriant, R. (2014). Hubungan Umur dan Lamanya Hemodialisis dengan Status Gizi pada Penderita Penyakit Ginjal Kronik yang menjalani Hemodialisis di RS. Dr. M. Djamil Padang. Jurnal Kesehatan Andalas, 3(3), 381386.

Ullu,arah murni,. nurina, . wahyuningrum. (2018). Hubungan Status Nutrisi Dengan Kualitas Hidup Pasien Gagal Ginjal Kronik Yang Menjalani HEMODIALISIS DI RSUD PROF. DR. W. $Z$. JOHANNES. Cendana Medikal Journal, 15(4), 425-437.

Widyastuti, R., Butar-butar, W., \& Bebasari, E. (2014). Korelasi Lama Menjalani Hemodialisis Dengan Indeks Masa Tubuh Pasien Gagal Ginjal Kronik DI RSUD Arifin Achamad Povinsi Riau pada Bulan Mei Tahun 2014. Jom FK, 1(2), 11. 